\title{
MANAJEMEN KOMUNIKASI DAN INTERPRETASI DIRI SEBAGAI PEMBEKALAN DUNIA KERJA (SMK YADIKA - JAKARTA)
}

\author{
Oktafalia Marisa Muzammil ${ }^{1)}$, Janny Rowena ${ }^{2) * d a n ~ A n d r e a s ~ W i j a y a ~}{ }^{3)}$ \\ ${ }^{1)}$ Manajemen/Fakultas Ilmu Sosial dan Humaniora, Universitas Bunda Mulia \\ ${ }^{2}$ Manajemen/Fakultas Ilmu Sosial dan Humaniora, Universitas Bunda Mulia \\ ${ }^{3)}$ Manajemen/Fakultas Ilmu Sosial dan Humaniora, Universitas Bunda Mulia
}

Diterima 28 Februari 2020 / Disetujui 20 Maret 2020

\begin{abstract}
According to surveyd had been done from (BPS), the number of unemployed people in Indonesia as of August 2018 reaching 7,000,000 people. This figure is equivalent to 5.34\% of the total workforce in Indonesia, which is $131,010,000$ people. The number of job vacancies always prioritizes the good educational background, the data had been shown: most absorbed graduates are graduate and postgraduate graduates, and professions while the lowest percentage of employment is secondary school graduates. Therefore at this time community services made a theme to providing communication and self-interpretation as a briefing for the world of work will be held in (SMK Yadika - Jakarta). Total sample of 125 students were collected in this session an being divided into two groups in this activity. The method used is the development of Laswell's theory through 5 main stages. The first session will be given direction by the lecturers on communication management starting from the definition, development, and implementation, which is then followed by a role play session. The second session, continued with interviews between students and lecturers. Through this interview session students are given directions on how to communicate well. At the end of the session the students were given one chance to do a review to meet a good interview standard. Based on the results, the participants could see that the students responded actively and enthusiastically in this activity.
\end{abstract}

Keywords: Lasswell Communication Model, Interview Method, Self Interpretation,

\begin{abstract}
ABSTRAK
Badan Pusat Statistik (BPS) mencatat jumlah pengangguran di Indonesia per Agustus 2018 mencapai 7.000.000 orang. Angka tersebut setara dengan 5,34\% dari jumlah angkatan kerja di Indonesia yang tercatat sebesar 131.010.000 orang. Jumlah lowongan pekerjaan yang mengutamakan latar belakang pendidikan menunjukan data bahwa lulusan yang paling terbesar diserap adalah lulusan sarjana dan pasca sarjana, dan profesi sedangkan persentase terendah penyerapan tenaga kerja adalah lulusan sekolah menengah. Maka dari itu pengabdian pada kali ini dengan tema pembekalan komunikasi dan interpretasi diri sebagai pembekalan dunia kerja akan diadakan di (SMKYadika - Jakarta). Total sampel sebanyak 125 siswa/i yang terbagi menjadi dua kelompok dalam kegiatan ini. Metode yang digunakan merupakan pengembangan dari teori Laswell melalui 5 tahapan utama. Sesi pertama akan diberikan arahan oleh para dosen mengenai manajemen komunikasi mulai dari definisi, pengembangan, dan implementasi, yang kemudian dilanjutkan dengan sesi role play. Sesi yang kedua, dilanjukan dengan wawancara antara siswa dengan dosen. Melalui sesi wawancara ini siswa diberikan arahan bagaimana cara berkomunikasi yang baik. Diakhir sesi para siswa diberikan satu kali kesempatan kembali untuk melakukan reka ulang agar dapat memenuhi standar wawancara yang baik.Berdasarkan hasil dari pengabdian kali ini ini, dapat dilihat para peserta yaitu para siswa/i menanggapi dengan aktif dan bersemangat dalam kegiatan ini.
\end{abstract}

Kata Kunci: Model Komunikasi Lasswell, Metode interview. Interpretasi diri

Corresponding Author: Omuzammil@bundamulia.ac.id 


\section{PENDAHULUAN}

Badan Pusat Statistik (BPS) mencatat jumlah pengangguran di Indonesia per Agustus 2018 mencapai 7.000 .000 orang. Angka tersebut setara dengan 5,34\% dari jumlah angkatan kerja di Indonesia yang tercatat sebesar 131.010.000 orang. Sementara untuk jumlah pengangguran per Februari 2019 turun menjadi 6.820 .000 orang. Disebutkan juga bahwa pengangguran yang paling banyak adalah lulusan SMK. Padahal saat ini Indonesia sedang menuju pada era era bonus demografi dengan jumlah penduduk usia produktif (berusia 15-64 tahun) lebih besar dibandingkan penduduk usia tidak produktif (berusia di bawah 15 tahun dan di atas 64 tahun) yang diprediksi akan memuncak pada tahun 2030-2040.

Jika dilihat dari suplai, maka yang terjadi adalah akan semakin banyak lulusan SMK dan perguruan tinggi yang nantinya akan bersaing di pasar kerja. Sekolah Menengah Kejuruan (SMK) adalah salah satu bentuk satuan pendidikan formal yang menyelenggarakan pendidikan kejuruan pada jenjang pendidikan menengah sebagai lanjutan dari SMP/MTs atau bentuk lain yang sederajat atau lanjutan dari hasil belajar yang diakui sama/setara SMP/MTs.Seharusnya lulusan SMK akan menjadi tenaga kerja yang siap pakai, di mana setelah lulus sekolah dapat langsung bekerja. Tetapi kenyataan menunjukkan hal yang berbeda. Berdasarkan data yang diambil dari Lokadata (2018), jumlah lowongan pekerjaan yang mengutamakan latar belakang pendidikan menunjukan data bahwa lulusan yang paling terbesar diserap adalah lulusan sarjana dan pasca sarjana, dan profesi sedangkan persentase terendah penyerapan tenaga kerja adalah lulusan sekolah menengah, walaupun nantinya dapat memberikan kesempatan bagi lulusan SMK untuk melanjutkan pendidikan, akan tetapi nantinya bagi lulusan SMK yang siap kerja tentu saja akan dihadapkan pada persaingan yang tidak menguntungkan.

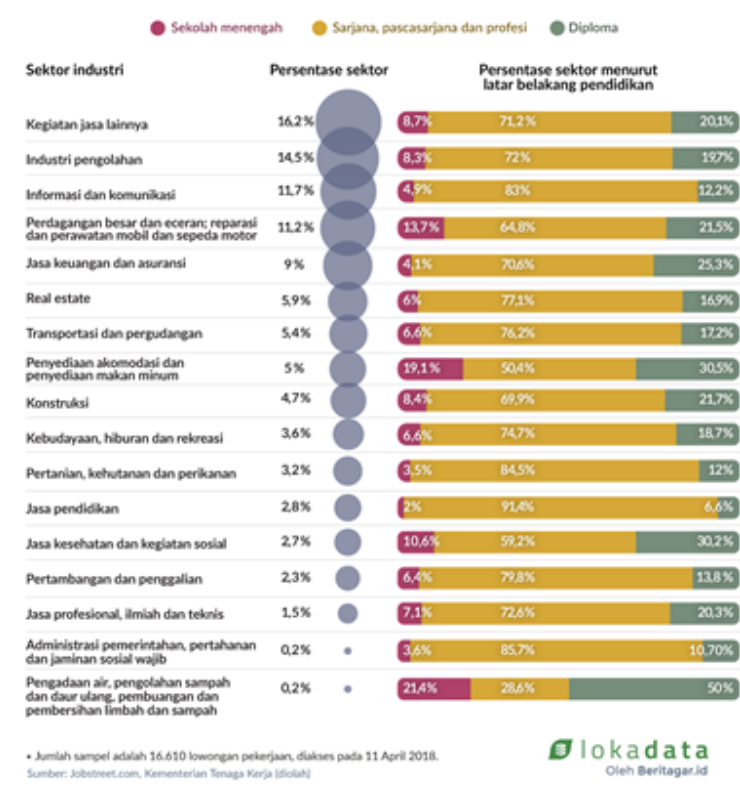

Gambar 1

\section{Lowongan Pekerjaan Berdasarkan Sektor Industri dan Latar Belakang Pendidik}

Sumber : Lokadata (2018)

Menghadapi hal ini, Mengutip dari LIPI yang turut serta mengungkapkan masalah ketenagakerjaan yang perlu diperhatikan dan dicarikan jalan keluarnya adalah kurangnya kompetensi dan daya saing tenaga kerja Indonesia. Apalagi dalam menghadapi revolusi industri 4.0, tenaga kerja Indonesia dianggap belum memiliki kesiapan dan keterampilan (skill) yang mumpuni. Kekurangan keahlian turut disebabkan oleh rendahnya pelatihan keterampilan baik ditempat kerja ataupun sebelum memasuki dunia kerja melihat hal ini, perlu diadakan perbaikan dari generasi muda yang siap masuk ke usia produktif agar siap bersaing menghadapi era bonus demografi. Pembekalan awal yang paling baik adalah dengan komunikasi menggunakan pendekatan model Lasswell untuk menyusun CV serta role play wawancara kerja sebagai bagian dari interpretasi diri. Hal ini dapat menjadi langkah awal bagi para siswa/i sebagai bekal agar nantinya dapat melakukan komunikasi 
baik selama sesi wawancara, maupun pada saat sudah masuk ke dunia kerja sehingga dapat menunjukan interpretasi diri yang baik yang akan mengarah kepada kompetensi diri. Maka dari itu pengabdian pada kali ini dengan tema pembekalan komunikasi dan interpretasi diri sebagai pembekalan dunia kerja akan diadakan di (SMKYadika Jakarta)

\section{IDENTIFIKASI MASALAH}

1. Badan Pusat Statistik (BPS) mengenai tingkat pengangguran terbuka (TPT) per Februari 2019 sebanyak 6.820 .000 orang. Jumlah pengangguran yang setara $5,01 \%$ dari jumlah angkatan kerja 136.180.000 orang paling tinggi masih lulusan Sekolah Menengah Kejuruan (SMK).

2. Saat ini Indonesia sedang menuju pada era era bonus demografi dengan jumlah penduduk usia produktif (berusia 15-64 tahun) lebih besar dibandingkan penduduk usia tidak produktif (berusia di bawah 15 tahun dan di atas 64 tahun) yang diprediksi akan memuncak pada tahun 20302040.

3. Lulusan yang paling terbesar diserap adalah lulusan sarjana dan pasca sarjana, dan profesi sedangkan persentase terendah penyerapan tenaga kerja adalah lulusan sekolah menengah.

4. Menghadapi revolusi industri 4.0, tenaga kerja Indonesia dianggap belum memiliki kesiapan dan keterampilan (skill) yang mumpuni. Kekurangan keahlian turut disebabkan oleh rendahnya pelatihan keterampilan baik ditempat kerja ataupun sebelum memasuki dunia kerja

5. Pada kegiatan pengabdian kali ini, sasaran peserta adalah siswa/i kelas XII dari SMK Yadika Jakarta Barat.

\section{TUJUAN DAN MANFAAT KEGIATAN}

Adapun maksud dan tujuan diselenggarakan kegiatan PKM ini adalah untuk :

a. Menambah wawasan siswa-siswi SMK tentang wawancara kerja melalui role play

b. Membekali siswa-siswi SMK agar dapat menyusun isi pesan komunikasi dalam menghadapi wawancara kerja.

\section{TINJAUAN PUSTAKA}

\section{Manajemen Komunikasi}

Manajemen adalah proses yang bertujuan untuk mencapai suatu tujuan dengan efektif dan efisien menggunakan semua sumber daya yang ada. Kata manajemen diambil dari kata kerja "manage" yang mengandung arti mengemudikan, mengurus dan mengarahkan.

Lebih lanjut, George R. Terry,1958 dalam bukunya Principles of Management membagi empat fungsi dasar manajemen yang disingkat dengan POAC, yaitu:

- Planning (Perencanaan),

George R. Terry dalam bukunya Prinsip - Prinsip Manajemen (2013) mengemukakan tentang Planning sebagai berikut, yaitu "Planning is the selecting and relating of facts and the making and using of assumptions regarding the future in the visualization and formulation to proposed of proposed activation believed necesarry to accieve desired result".

Dari pembahasan diatas dapat diartikan bahwa Perencanaan adalah pemilih fakta dan penghubungan fakta-fakta serta pembuatan dan penggunaan perkiraan-perkiraan atau asumsi- 
asumsi untuk masa yang akan datang dengan jalan menggambarkan dan merumuskan kegiatan-kegiatan yang diperlukan untuk mencapai hasil yang diinginkan."

- Organizing (Pengorganisasian)

Pengorganisasian tidak dapat diwujudkan tanpa ada hubungan dengan yang lain dan tanpa menetapkan tugas-tugas tertentu untuk masing-masing unit. George R. Terry dalam bukunya Prinsip Prinsip Manajemen (2013) mengemukakan tentang organizing sebagai berikut, yaitu "Organizing is the determining, grouping and arranging of the various activities needed necessary forthe attainment of the objectives, the assigning of the people to thesen activities, the providing of suitable physical factors of enviroment and the indicating of the relative authority delegated to each respectives activity.

Dari definisi diatas dapat diambil kesimpulan, pengorganisasian aalah penentuan, pengelompokkan, dan penyusunan macam-macam kegiatan yang dipeelukan untuk mencapai tujuan, penempatan orang-orang (pegawai), terhadap kegiatankegiatan ini, penyediaan faktorfaktor physik yang cocok bagi keperluan kerja dan penunjukkan hubungan wewenang, yang dilimpahkan terhadap setiap orang dalam hubungannya dengan pelaksanaan setiap kegiatan yang diharapkan.

- $\quad$ Actuating (Pelaksanaan)

Menurut R. Terry dalam bukunya Prinsip - Prinsip Manajemen (2013) mengatakan bahwa : Actuating is setting all members of the group to want to achieve and to strike to achieve the objective willingly and keeping with the managerial planning and organizing efforts.

Dari definisi diatas dapat diambil kesimpulan, pelaksanaan adalah membangkitkan dan mendorong semua anggota kelompok agar supaya berkehendak dan berusaha dengan keras untuk mencapai tujuan dengan ikhlas serta serasi dengan perencanaan dan usahausaha pengorganisasian dari pihak pimpinan.

- Controlling (Pengawasan).

Menurut George R. Terry dalam bukunya Prinsip - Prinsip Manajemen (2013) Control mempunyai perananan atau kedudukan yang penting sekali dalam manajemen, mengingat mempunyai fungsi untuk menguji apakah pelaksanaan kerja teratur tertib, terarah atau tidak. Walaupun planning, organizing, actuating baik, tetapi apabila pelaksanaan kerja tidak teratur, tertib dan terarah, maka tujuan yang telah ditetapkan tidak akan tercapai. Dengan demikian control mempunyai fungsi untuk 
mengawasi segala kegaiatan agara tertuju kepada sasarannya, sehingga tujuan yang telah ditetapkan dapat tercapai.

Komunikasi dalam pengabdian ini menggunakan model komunikasi dari Lasswell yang dicetuskan pada tahun 1948 . Teori ini adalah teori yang paling awal dalam perkembangan teori komunikasi. Definisi komuniasi menurut (Lasswell 1948:. Komunikasi pada dasarnya merupakan suatu proses yang menjelaskan siapa? mengatakan apa? dengan saluran apa? kepada siapa? dengan akibat atau hasil apa?. Model komunikasi dari Laswell pada awalnya banyak digunakan sebagai bentuk interpretasi pesan yang disampaikan menggunakan media, namum dalam perkembanganya model teori tersebut banyak di pakai dalam berbagai bidang seperti yang dilakukan pada praktik manajemen sumber daya manusia oleh Alston (2017) dengan menggunakan model Lasswell untuk melakukan pelatihan karyawan melalui $5 \mathrm{~W}$, yaitu :

1. Who (siapa),

Who dapat diartikan sebagai sumber atau komunikator yaitu, pelaku utama atau pihak yang mempunyai kebutuhan untuk berkomunikasi dan yang memulai suatu komunikasi, bisa seorang individu, kelompok, organisasi, maupun negara sebagai komunikator

2. Says what (isi pesan)

Apa yang akan disampaikan atau dikomunikasikan kepada penerima (komunikan), dari sumber (komunikator) atau isi informasi.Merupakan seperangkat symbol verbal/non verbal yang mewakili perasaan, nilai, gagasan dan maksud sumber .

3. In which channel (medium), medium adalah suatu alat untuk menyampaikan pesan dari komunikator (sumber) kepada komunikan (penerima) baik secara langsung (tatap muka) maupun tidak langsung .

\section{To whom (penerima pesan)}

Sesorang yang menerima siapa bisa berupa suatu kelompok, individu, organisasi atau suatu Negara yang menerima pesan dari sumber.Hal tersebut dapat disebut tujuan (destination), pendengar (listener), khalayak (audience), komunikan, penafsir, penyandi balik (decoder).

5. With what effect (dampak yang ditimbulkan)

Dampak atau efek yang terjadi pada komunikan (penerima) seteleh menerima pesan dari sumber seperti perubahan sikap dan bertambahnya pengetahuan.

6. seperti pada gambar 2 di bawah ini

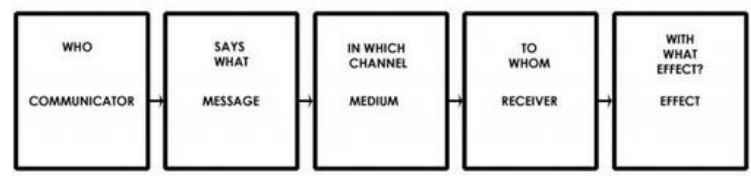

Gambar 2

\section{Model Komunikasi Lasswell}

\section{Wawancara kerja}

Menurut Dessler (2015) wawancara kerja adalah suatu jenis tahapan dalam seleksi kerja yang melibatkan percakapan antara pelamar/pencari kerja dengan pihak perwakilan dari organisasi yang mempekerjakan untuk melihat, apakah calon 
pekerja merupakan kandidat yang tepat atau tidak.

Tiga cara untuk membuat wawancara lebih berguna (Dessler, 2015) :
a. Gunakan wawancara situasional terstruktur
b. Ketahui apa yang akan ditanyakan
c. Berhati-hati agar tidak melakukan kesalahan wawancara

Kesalahan yang dapat mengurangi kegunaan wawancara (Dessler, 2015) :
a. Kesan pertama (penilain seketika)
b. Tidak mengklarifikasi apa yang dibutuhkan pekerjaan
c. Kesalahan urutan kandidat (kontras) dan tekanan untuk merekrut
d. Perilaku nonverbal dan manajemen impresi
e. Pengaruh karakteristik personal : daya tarik, gender, ras

\section{Interpretasi Diri}

Interpretasi diri dapat diartikan sebagai proses komunikasi melalui lisan atau gerakan antara dua atau lebih pembicara yang tak dapat menggunakan simbol-simbol yang sama, baik secara simultan (dikenal sebagai interpretasi simultan) atau berurutan (dikenal sebagai interpretasi berurutan). Moran (1994) menejelaskan juga untuk mengukur interpretasi diri membutuhkan pihak dari orang pertama sampai dengan pihak ke tiga. Medium dalam kegiatan ini menggunakan CV (Curiculum Vitae) merupakan dokumen yang beriisikan perkenalan diri secara tidak langsung (tertulis) mengenai data personal dan data latar belakang pendidikan kepada pihak yang dituju. Agar pembuatan CV sesuai dengan nama, data probadi, kontak, atau media komunikasi yang digunakan, maka, pada kegiatan ini siswa dapat bertindak sebagai pihak pertama pengirim pesan dengan siswa lainnya sebagai pihak kedua sebagai penerima pesan dan dosen sebagai pihak ketiga untuk menilai hasil dari interpretasi diri dengan medium surat lamaran $(\mathrm{CV})$.
Jenis - Jenis Curiculum Vitae antara lain:

- CV berdasarkan ketentuan

CV yang strukturnya sudah ditentukan oleh perusahaan atau instansi yang menyediakan lapangan pekerjaan.

Contoh : CV untuk melamar sebagai PNS (Pegawai Negri Sipil), militer, BUMN (Badan Usaha Milik Negara), atau perusahaan konservatif yang sudah memiliki dan membentukan bentuk baku dari Curiculum Vitae

\section{- CV berdasarkan tujuan}

$\mathrm{CV}$ jenis ini sangat tergantung tujuan dari perusahaan yang dituju ataupun bidang kerja yang diminati. Sehingga segala hal yang tidak berhubungan dengan tujuan tidak perlu di tulis dalam CV ini, karena itu dalam membuat $\mathrm{CV}$ berdasarkan tujuan membutuhkan informasi yang cukup jelas tentang tujuan

\section{METODE PENELITIAN}

Kegiatan pengabdian kepada masyarakat ini menggunakan teknik pengambilan data berupa purposive sampling. Menurut Wijaya (2019) purposive sampling berarti mengambil sampel yang memenuhi kriteria yang diperlukan untuk menjadi subjek. Kriteria yang diperlukan adalah siswa/i yang sudah berada pada jenjang SMK kelas XII. Total sampel sebanyak 125 siswa/i yang terbagi menjadi dua kelompok dalam kegiatan ini. Metode yang digunakan merupakan pengembangan dari teori Laswell melalui tahapan who (siswa sebagai pelamar), says what (isi lamaran kerja), in which channel (surat lamaran), to whom (HRD), with what effect (mendapatkan masukan yaitu: surat lamaran yang baik akan dilanjutkan dengan 
wawancara) yang dikembangkan seperti gambar 3 di bawah ini:

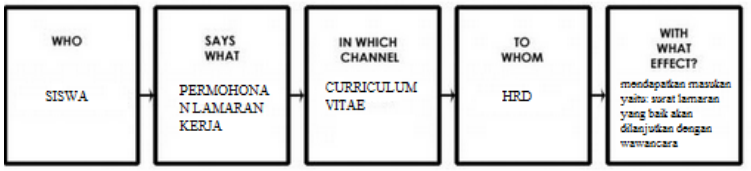

Gambar 3

\section{Pengembangan Model Komunikasi Lasswell}

Sesi pertama akan diberikan arahan oleh para dosen mengenai manajemen komunikasi mulai dari definisi, pengembangan, dan implementasi, yang kemudian dilanjutkan dengan sesi role play sesuai dengan model komunikasi dari Lasswell. Sesi selanjutnya dilanjutkan dengan feedback (umpan balik) melalui tahapan wawancara bagi siswa yang memenuhi syarat dalam pembuatan $\mathrm{CV}$.

\section{HASIL DAN PEMBAHASAN}

Hasil dalam pengabdian ini akan dijabarkan melalui dua sesi yang dilakukan. Pada sesi pertama para dosen meemberikan seputar pengetahuan mengnai manajemen komunikasi sebagai arahan melakukan roleplay seperti yang dapat dilihat pada gambar 4

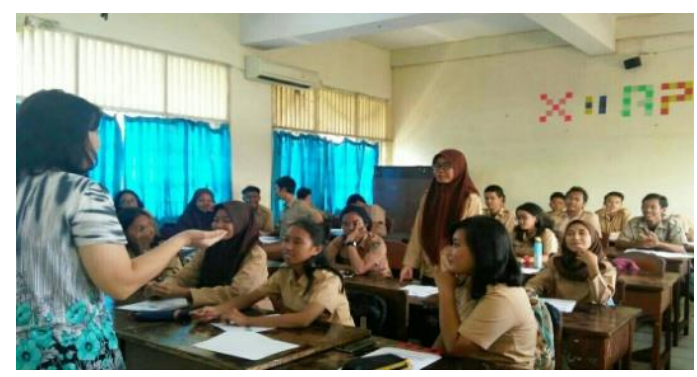

Gambar 4. Pemberian arahan Roleplay

Setelah menerima arahan yang diberikan, para siswa/i membuat CV (surat lamaran) yang menjadi medium untuk mengkomunikasikan diri kepada pemberi kerja atau pihak HRD. Total sebanyak 45 siswa yang berhasil memenuhi kriteria standar dalam pembuatan $\mathrm{CV}$, dengan catatan kriteria pembuatan $\mathrm{CV}$ yang baik menurut Havard Bussiness Review (2014), yaitu:

- Mengirimkan isi lamaranan sesuai dengan lowongan yang dibutuhkan

- Identitas Diri. Tuliskan nama lengkap Anda, alamat, nomor telepon dan alamat email serta jangan lupa untuk menyertakan Jenjang Pendidikan dan pas foto terbaru Anda.

- Paparkan secara singkat, padat dan jelas mengenai karakter Anda dan nilai-nilai kehidupan yang Anda junjung.

- Deskripsikan keterampilan serta skill yang Anda miliki terutama yang menunjang pekerjaan yang menjadi sasaran Anda.

- Tuliskan pengalaman kerja Anda dan pencapaian serta penghargaan yang pernah diraih apabila ada.

- Cantumkan pelatihan yang pernah Anda ikuti yang menambah skill.

- Cantumkan informasi tentang diri Anda yang relevan dengan pekerjaan Anda dan juga referensi dari beberapa orang penting di perusahaan, tempat Anda bekerja sebelumnya.

Sebaliknya, yang tidak perlu ditampilkan dalam CV adalah:

- Memperhatikan kosakata dan meminimalisir typo

- Penggunaan wording agar mudah dimengerti oleh pembaca

Sesi yang kedua, dilanjukan dengan wawancara antara siswa dengan dosen. Melalui sesi wawancara ini siswa diberikan arahan bagaimana cara berkomunikasi yang baik melalui 3 poin utama, antara lain:

1. Cara Berpakaian Saat Wawancara Kerja 
- Bagi pria :

- Celana panjang

- Kemeja / jas

○ Ikat pinggang

- Kaus kaki dan sepatu

- Jangan terlalu berlebihan menggunakan parfum

- Bagi wanita:

- Rok/ celana panjang

- Blus/ atasan dengan corak sederhana atau polos

- Sepatu tertutup dengan hak maksimal $5 \mathrm{~cm}$

- Gunakan riasan tipis

- Jangan terlalu berlebihan menggunakan parfum

- Jangan gunakan asesoris berlebihan

2. Bahasa Tubuh Yang Baik Saat Wawancara Kerja

- Sopan menyambut pewawancara

- Jabat tangan dengan tegas

- Jaga kontak mata

- Mengangguk sambil menyimak

- Menggerakkan tangan secukupnya

- Jaga postur duduk, jangan terlalu menjauh ke belakang ataupun condong ke depan.

- Posisi tangan. Jangan sekali-kali menyilangkan di depan dada, memasukkan dalam saku, atau melakukan gerakan tangan yang nggak sinkron dengan pertanyaan

- Berikan senyum sewajarnya

3. Pertanyaan Yang Paling Sering Muncul Di Wawancara Kerja

- Bisakah Anda menceritakan soal diri Anda?

- Mengapa Anda meninggalkan/ berniat meninggalkan pekerjaan terakhir Anda?

- Kenapa kami harus mempekerjakan Anda?

- Apa saja kelebihan yang Anda miliki?
- Apa yang Anda ketahui dari perusahaan ini?

- Apakah Anda ada pertanyaan untuk saya?

Setelah memberikan arahan ini, para siswa diberikan satu kali kesempatan kembali untuk melakukan reka ulang agar dapat memenuhi standar wawancara yang baik.

Berdasarkan hasil dari pengabdian kali ini ini, dapat dilihat para peserta yaitu para siswa/i menanggapi dengan aktif dan bersemangat dalam kegiatan ini, oleh karena itu dapat dikembangkan lagi lebih lanjut untuk mengadakan kembali pengabdian kepada masyarakat dengan bentuk pelatihan dengan tema "public speaking" sebagai lanjutan bagi para siswa dalam hal teori manajemen komunikasi agar menjadi bekal untuk semakin percaya diri menghadapi persaingan pasar tenaga kerja yang kian kompetitif.

\section{DAFTAR PUSTAKA}

Alston (2017) Service Standards in Higher Education: Lasswell's Communication Model as a Training Tool. Illinois University.

Dessler, G. (2015). Manajemen Sumber Daya Manusia. Jakarta: Salemba Empat

Lasswell, H. 1948. "The Structure Function of Communication in Society", The. Communication of Ideas. Institute for Religious and Social Studies. New. York.

Richard Moran (1994). Interpretation Theory. The Philosophical Quarterly, Vol. 44, No. 175 (Apr., 1994), pp. 154-173

Wijaya, A. (2019). Metode Penelitian Menggunakan Smart PLS 03 (1st ed.). Jakarta: Innosains.

Terry, G.R (2013) Prinsip - prinsip Manajemen. Cetakan ke 11. Bumi Aksara

https://tirto.id/c9c9

https://beritagar.id/artikel/berita/masih-ada-7juta-pengangguran-di-indonesia

https://hbr.org/2014/12/how-to-write-aresume-that-stands-out 